The objections I have registered here may finally be unfair. Perhaps Nick Selby was quite aware of the books and articles cited above but felt forced to exclude them in order to remain within publisher-imposed page or word limits. Perhaps he could have reprinted far more extracts than he did but chose not to strive for a reader-unfriendly exhaustiveness. In the end he created a praiseworthy book, but its user should bear in mind that it does not relate the whole story.

\title{
University of Wisconsin-Parkside
}

Donald D. Kummings

Judith Grace. Good-bye my Fancy: With Walt Whitman in His Last Days. Oregon House, CA: Ulysses Books, 2004. 119 pp.

Judith Grace has had the excellent idea of sifting through the volumes of Horace Traubel's With Walt Whitman in Camden with a view to creating a literarycelebrity play in the tradition of Jerome Kilty's Dear Liar (1959), which brought Bernard Shaw and Mrs. Patrick Campbell on stage, Michael Hastings' Tom and Viv (1984), about the first marriage of T. S. Eliot, and several Oscar Wilde dramas. The result not only captures the alternately homely and fiery spirit of Traubel's monumental oral history project; it also strikes this reader as no mere closet drama. The Leaves of Grass sesquicentennial next year ought to inspire some enterprising producers to give Good-bye my Fancy a stagingif, that is, they can find skilled actors for the tour de force role of the voluble valetudinarian and the role of his wry, rather laconic young "background man."

Grace's "Dialogue in Three Parts" unfolds entirely in Whitman's Camden, New Jersey, upstairs bedroom-study on three evenings: in November 1890, on the poet's birthday the next year, and on his deathday, March 26, 1892. The first two parts are longer and contain most of the conversational drolleries and fireworks; the third part, necessarily, is shorter but offers several deeply affecting moments.

Walt predicted that Horace's busy note-taking would capture "the pulse and throb of the critter" he was better than any biographer could, and Grace has succeeded in preserving that pulse and throb while quilting together many choice patches of Mickle Street chat. "The poetic license is minimal," Robert MacIsaac (a co-editor of the last two With Walt Whitman in Camden volumes) accurately observes in his introduction. The most notable concession to theatrical license, he also grants, are the few instances in which Grace has Walt uncharacteristically recite lines from Leaves of Grass. "Song at Sunset" is movingly worked into Part II, as is the poem of the title in the denouement. Appended is a short informational essay on "Walt Whitman and Horace Traubel" by Thomas Fenn.

Good-bye my Fancy's chief pleasure and value are that it retires (at least temporarily) that benign eminence, the Famous Good Gray Poet, and introduces a mercurially witty, angry, quizzical, clear-eyed, weary-bodied, or passionate Walt-a Walt far more candid than he ever would have been in the formal public utterances of his last decade. 
Many of my favorite passages in With Walt Whitman that Grace has made use of have a particularly timely ring to them, another argument for getting the play on stage. One is reminded that Whitman was, finally, deeply angry at the America of his day (as so many Americans are now) when he observes, "I get mad at people, then people get mad at me. That's the way we even up." His recollections of nursing - "I always kept an outward calm in going among them - had to-would have been useless if I hadn't." - resonate as American military hospitals, notably in or near Washington, are again very busy. His famous "God damn 'em!" outburst at all wars is breathtakingly apropos, especially his acid remark, "The people who like the wars should be compelled to fight the wars." As for the current culture war over marriage, perhaps Whitman puts it all sanely in context when Traubel asks him about the institution: "I don't know about marriage. But about love-well love will always take care of itself." Horace then goads him for his view on free love, to which Walt ripostes, without missing a beat, "Is there any other kind of love?"

"No story is complete without the slaps as well as the kisses," Whitman said of his career, and Part II includes a touching meditation on how long it had taken for the kisses to start coming: " $O$ the mutations of years! . . . The world did not want me. Now comes a multitude ... after I am wrecked, stranded, left but to look for the end." Also affecting is the inclusion of Whitman's withering condemnation of a world "so afraid to love, so afraid to demonstrate, so good, so respectable, so aloof"-and so shocked and gossipy at "any demonstration between men."

One mistake can be easily corrected. Horace asks Walt, "do you remember the day you buried your brother, little Walter?" That should be "nephew," the namesake son of George Whitman, who died before his first birthday.

Finally, I cannot resist kibitzing over the way Grace ends her theater piece: Walt cries out his last words ("Shift! Shift!" - that is, reposition his body) and expires; Horace then bends over him and utters a one-line farewell. Much better to have Horace, now becoming a "foreground man" at last, step to the forestage and, to a slow fade, address the audience — and posterity-with this gooseflesh-raising valediction he put toward the end of his entry for W.alt's last day:

I laid his hand quietly down - something in my heart seemed to snap and that moment commenced my new life-a luminous conviction lifting me with him into the eternal. . . . The life had gone out at sunset - the light of day not yet utterly gone- the last rays floating with timid salutation into the gloom . . . all was peaceful, beautiful, calm, fitting. . . . I leaned down and kissed him, hand and head-and then I went out, shadowed, into the penetrating night. 